\title{
License with care
}

\begin{abstract}
University technology transfer offices are tasked with helping bring the inventions made by academics to the attention of potential investors. But selling off intellectual property to patent aggregators in an effort to bring in money to their institutions could stifle the future development of new technologies.
\end{abstract}

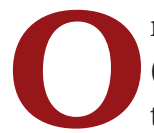
n September 27, the US Federal Trade Commission (FTC) announced that it would look into the potentially anticompetitive practices of so-called 'patent trolls' or 'patent assertion entities' (PAEs). These are companies that buy or license and aggregate large numbers of patents with the stated goal of helping to develop those inventions so they can be more easily brought to market. But, troublingly, PAEs have also extensively used those patents to sue companies that may be infringing on the intellectual property-last year, over 100,000 companies were targeted with lawsuits by PAEs. As engines of new ideas, universities have vast patent holdings that they need to develop and monetize; some of these institutions are turning to PAEs to serve as a new revenue stream. But technology transfer offices should be wary of PAEs and should realize that taxpayerfunded research needs to stay out of the hands of those whose use of the legal system may obstruct innovation.

A US Executive Office of the President report published in June (http://www.whitehouse.gov/sites/default/files/docs/patent_ report.pdf) found that $62 \%$ of all patent lawsuits in 2012 in the US were initiated by PAEs, up from around $20 \%$ in 2006 . A recent study estimated that legal actions brought by PAEs have cost companies $\$ 500$ billion over the past 20 years (doi:10.2139/ ssrn.2091210).

The startups that are creating new products are often so small that they cannot afford lengthy court battles. They therefore opt for a financial settlement instead of taking the case to court. Because PAEs are not creating products in house, they cannot be countersued for infringement, so their legal risks are relatively low. In addition, many patents are very broad, covering a general business process rather than a specific product, for example. This makes it easier for litigants to claim patent infringementand possibly to win in court.

Patent lawsuits tend to stifle product development even before the case is decided because the companies fear they could be charged with 'willful infringement' and may therefore need to pay additional damages if they continue to work on the product. For example, a study published in March showed that medical imaging firms that were sued by a PAE slowed development of their digital medical image storage software compared with firms that were not sued (doi:10.2139/ssrn.1976593).

Generally, only about $5 \%$ of patents that are generated by a university are licensed. But in a few universities that have extensive relationships with PAEs, the number has climbed to $15 \%$. Unlicensed patents consume scarce financial resources because they still need legal and administrative attention to be maintained, so the aim to turn those unlicensed patents into revenue for the university is certainly understandable. But these patents are often generated from federally funded research, so the acquisition of patents by PAEs that then use them to pursue legal actions against entrepreneurial companies, although legal, is antithetical to the intent of public funding for research.

Congress is also getting the picture that PAEs could be bad for business. Already this year, there have been six separate bills put forward in Congress that would serve to regulate the actions of PAEs. One bill, the SHIELD Act, would require PAEs that lose their lawsuits to pay the legal fees of the companies that they had sued. Another bill, the STOP Act, would require the US Patent Trademark Office to closely reexamine patents that are cited in potential lawsuits to prevent frivolous infringement claims.

Even if these bills don't pass, two cases the US Supreme Court agreed this month to hear could make PAEs think twice before filing infringement lawsuits. Both those cases involve whether those who lose patent lawsuits should pay the legal costs of the winner. The decisions of the lower courts currently mandate payment of legal fees by the loser only if the case is "exceptional," meaning that the lawsuit is objectively frivolous. The Supreme Court will decide whether that standard is too restrictive.

The litigious nature of PAEs should compel universities not to relinquish full control over their intellectual property to those companies, perhaps by including legal riders in their licensing agreements to make it more difficult for their patents to be used to sue entrepreneurial ventures that aim to develop the technologies. PAEs might be here to stay, but universities have the responsibility to ensure that their patents serve the public good rather than lining the pockets of PAEs. 